\title{
J S Semler (1725-1791) se beskouing van geskiedenis, kerkgeskiedenis en heils- geskiedenis - 'n Verkenning
}

\author{
Christo Pretorius \& S J Botha \\ Departement Kerkgeskiedenis (Afd A) \\ Universiteit van Pretoria
}

\begin{abstract}
J S Semler's (1725-1791) view of history, church history and salvation history - An exploration

Johan Solomon Semler introduced a new understanding of Scripture through his view of history. This article tries to indicate that the scheme according to which he viewed history is one based on the distination between content and form. By means of this scheme, Semler endeavoured to reconcile faith and revelation with ideas from the Renaissance, Enlightenment and English Deism. Semler's premises were not just influenced by scholars like Leibnitz and Baumgarten, but his association with Pietisin and Orthodoxy further contributed to the formation of his view of history. However, as a result of his premises, Semler surrendered church history and salvation history to the Enlightenment view of history. Church history and salvation history were consequently interpreted in terms of progress in the perfection of morality. Unaware of his own historical position, Semler subjected the contents of church history and salvation history to his own premises.
\end{abstract}

\section{INLEIDING}

Die huidige debat in die teologie aangaande die invloed van 'n paradigmaverskuiwing van die moderne era na die postmoderne era, plaas Schleiermacher opnuut in die brandpunt. Ten opsigte van die verskuiwing verklaar Van Aarde: 'Dreyer is in 'n belangrike opsig reg deurdat hy die denke van Schleiermacher sien as die geboortegrond van die paradigmatiese verskuiwing wat tans in die teologie ervaar word' (Van Aarde 1995: 19). Wanneer Williston Walker (1986:629-630) die stelling maak dat Friedrich Daniel

* Hierdie artikel is 'n verwerking van die resultate van die MDiv-skripsie, ingedien en aanvaar as deel van die vereistes vir die MDiv-graad (1996), Departement Kerkgeskiedenis, Fakulteit Teologie (Afd A), Universiteit van Pretoria, onder leiding van prof dr S J Botha. 
Ernst Schleiermacher (1768-1834) deur Wolff en Semler beïnvloed word, moet die stelling verder nagevors word. Die invloed en denke van Semler kan lig werp op die verdere gang van die teologie, veral as in ag geneem word dat Semler deur Schulze (1988: 237) as die stigter van die histories-kritiese metode getipeer word en Karl Barth in verband met Semler se bydrae oordeel dat Semler se teologiese verdienste geheel en al op die gebied van die historiese metodologie lê. Barth (1946:150) sê verder dat: '.. er hat als Kirchenhistoriker das christologische und das soteriologische Dogma angegriffen.' Semler se bydrae tot die teologie word veral gemeet in terme van die historieskritiese metode van ondersoek en Lee noem in navolging van Krentz, Semler die vader van die histories-kritiese teologie (Krentz, in Lee 1992:16). Uit Barth se beoordeling is dit egter duidelik, dat Semler vanuit sy geskiedbeskouing 'n beduidende bydrae gelewer het. Trouens, vanuit sy geskiedbeskouing het hy 'n nuwe verstaan van die Skrif in die teologie ingebring. So verklaar Barth ondermeer:

\begin{abstract}
Er hat mit den bekannten historische Mitteln, aber doch auch bewaffnet mit dem Kriterium der sittlichen Brauchbarkeit die Autorität des biblischen Kanons angefochten, ferner die Gleichstellung der beiden Testamente, die Inspirations des biblische Textes, die identifizierung von Schrift und Offenbarung.
\end{abstract}

(Barth 1946:150)

Deur middel van die historiese ondersoek kom Semler tot die slotsom dat die Ou-Testamentiese en die Nuwe-Testamentiese kanon aan 'n historiese ontwikkeling onderworpe was en produk was van die historiese proses. Kraus (1956:98) verklaar ondermeer dat Semler veral van Richard Simon geleer het dat die Ou-Testamentiese kanon 'n historiese ontwikkeling deurgaan het en geleidelik ontstaan het. Semler [1782] verklaar hieroor in sy Lebensbeschreibung von ihm selbst abgefasst:

Ich habe nicht geradehin alle Bücher des alten und neuen Testaments für gleich unentbehrlich gehalten, um die Grundwahrheiten der christlichen eigenen Privatreligion richtig und vollständig zu sammeln; sie können alle nützlich sein für manche Christen, aber es ist kein christliche Lehrsatz, daß alle Christen aus allen Büchern des alten und neuen Testaments ihre Religion herleiten und zur Uberzeugung davon aus allen Büchern so oder so viel zusammentragen müßten.

(Semler, in Kraus 1956:98) 
Dat Semler vandag nog aktuele waarde het, kan afgelei word uit die verklaring van Schulze so onlangs as 1988 . Hy verklaar dat vanuit Semler (en Lessing) se denke daar 'n ontwikkelingslyn loop vanaf die inspirasieleer van die Ortodoksie, oor die historiese denke van die Verligting tot by die soeke na die historiese Jesus en die historisme van Ernst Troeltsch. Die moderne tendens van die ontmitologisering van die Skrif (Bultmann) en van die beklomtoning van die Skrif as getuienis van 'n woordgebeure binne die kringe van die Nuwe Hermeneutiek van Ebeling en Fuchs, is direkte uitvloeisel van hierdie proses (Schulze 1988:239). Vanuit sy geskiedbeskouing maak Semler 'n onderskeid tussen Woord van God en Bybel, tussen teologie en godsdiens en tussen private en openbare godsdiens. Hierdie geskiedbeskouing en die onderskeid tussen vorm en inhoud wat daaruit voortvloei, het 'n relativerende invloed op Bybelse gesag en leergesag en gevolglik dui Hans Küng Semler aan as die grondlegger van die moderne ondogmatiese kerk- en dogmengeskie-denis (Hans Küng, in Waldenfels 1977:64). Daar is dus genoegsame rede om aan Semler se beskouing van geskiedenis, kerkgeskiedenis en heilsgeskiedenis en dan veral wat sy vooronderstellings in hierdie verband betref, aandag te gee. Problematies is egter dat slegs 'n enkele werk, naamlik Abhandlung von freier Untersuchung des Canon (1772) in Suid-Afrika beskikbaar is. Verskeie werke van ander navorsers is wel be-skikbaar, waarin geredelik na Semler se werke en invloed verwys word. Hierdie bronne open minstens die moontlikheid om voorlopig en verkennend aan Semler aandag te gee. Selfs die voorlopige verkenning het egter uitgewys dat die onderwerp 'n groter studie as slegs 'n M Div skripsie verdien en dat dié verkenning die moontlikheid vir verdere navorsing open.

\section{J S SEMLER (1725-1791)}

\subsection{Biografiese gegewens}

Op 18 Desember 1725 word Semler in Saalfeld as seun van 'n aartsdeken gebore en hier kom Semler as kind in aanraking met die Piëtisme (Hess 1974:15). In 1743 studeer Semler aan die Universiteit van Halle. In Halle ontmoet Semler vir Baumgarten en word hierdie man se invloed merkbaar wanneer hy Semler motiveer om die Magisterstudie aan te pak. In 1750 promoveer Semler tot Magister in die filosofie op grond van sy dissertasie Vindiciae plurium praecipuarum lectionum codicis graeci novi testamenti adversus Guil. Whistonum. Hierin het hy onder andere die egtheid van 1 Timotheus 3:16 en 1 Johannes 5:7 teenoor W Whiston se Ariaanse verklaring verdedig. Hy lei sy dispuut in met die vraag: Quanam ratione recte laudentur humaniores litterae? (Semler, in Hess 1974:266). Bogenoemde vraag en sy geskrif Pensées hazardées sur quelques prejuges a l'égard des humanitez dediées (1750) dui reeds op 'n verdediging van 'n menslik gegronde ondersoek teenoor die pietistiese stroming. Deur 
Baumgarten (1706-1757) se bemiddeling word Semler ook na Halle beroep en volg hy vir Clausewitz in 1752 op (Hess 1974:281). In sy werk - D. Joh. Salomo Semlers Lebensbeschreibung von ihm selbst abgefasst, Zweiter theil, Halle 1782 - gee Semler te kenne dat hy hom vanweë Baumgarten se steun, vooruit die argwaan van die groter party - die sogenaamde Vromes - op die hals gehaal het. In hom bespeur hulle 'n navolger van Baumgarten se koue geleerdheid en volgens Hess word hy en Baumgarten in die fakulteitsvergaderings met ' $n$ '... merklichen Zurückhaltung ....' begroet. Dit blyk dat Semler hierdeur 'n mate van vervreemding ervaar en Hess verklaar dat die vertroue wat Semler by sy kollegas in die fakulteit soek en nie vind nie, hom uiteindelik laat opgaan in die akademie (Hess 1974:281). Die professoraat te Halle beklee hy tot met sy dood op 14 Maart 1791. Sy dienstyd te Halle is veral gekenmerk deur die invloed van Sigmund Jakob Baumgarten en stel Hess (1974:21) dat: 'Die Veränderung, die im Verlauf von Semlers Studium unter dem Einfluss Baumgartens eintrat ....' nie geïgnoreer word nie.

\subsection{Die invloed van Sigmund Jakob Baumgarten (1706-1757)}

Baumgarten word saam met Israel Gottlieb Canz (1690-1753) en Jakob Carpov (16991768) deur Karl Barth as ortodokse Wolffiane beskou (Barth 1946:135). Dit impliseer dat hulle navolgers van Christiaan Wolff was. Christiaan Wolff (1679-1754) word te Breslau gebore en in 1707 word hy professor in Wiskunde te Halle, maar in 1723 word hy deur Frederik Wilhelm I afgesit en verban. Dié verbanning moet teen die agtergrond van die noue band tussen die Piëtisme - onder die leiding van August Hermann Francke (1663-1727) - en die Pruisiese absolutisme van Frederik III gesien word (Beyreuther 1978:141). Halle word 'n bastion vir die Piëtisme, soseer dat Frederik Wilhelm I in 1727 bepaal dat '... alle Pfarrer, die in seinem Reich unterkommen wollten, ein Jahr in Halle studiert haben mussten' (Beyreuther 1978:151). Francke sien homself as die werktuig van God en verset hom ywerig teen Wolff se '... Automatismus und Determinismus ....' (Beyreuther 1978:172). Francke het vanweë sy teëstand ' $n$ beslissende rol in die verbanning van Christiaan Wolff gespeel. In 1740 word Wolff egter deur Frederik II heraangestel en word hy tot kanselier bevorder. Hagenbach (1896:944) verklaar ondermeer dat dit veral Leibniz se filosofie was wat deur Wolff ingang in die teologie gebied is, en Moeller stel dat Wolff nie werklik as verteenwoordiger van die Aufklärung beskou kan word nie maar wel as die gewisse voorloper en: '... dass er die Leibnizsche Philosophie zu einem wissenschaftssystem ausbaute und so den Rationalismus zum selbstverständlichen Prinzip aller wissenschaftlich Arbeit machte' (Moeller 1979:317). 
Vir Wolff was die harmonie tussen die rede en openbaring sy grondliggende teologiese oortuiging en hierdie strewe van die versoening tussen rede en openbaring word ook by Baumgarten gevind. Ernst Wolff dui aan dat Baumgarten deur rasionele deduksie en deur versigtige gebruik van nuwe natuurwetenskaplike en historiese denke die ortodokse dogma wou begrond. Hy wou, soos Christiaan Wolff, die openbaringsbegrip asook die openbaringsinhoud behou en met die rede harmonieer. Die Leibniz-Wolffiaanse wysbegeerte vind gaandeweg ingang tot die teologie, en hulle poog om 'n natuurlike godsdiens daar te stel wat onafhanklik van die openbaring is, maar nie in teenspraak met die openbaring nie. Hulle pogings om langs demonstratiewe weg 'n natuurlike godsdiens te verkry wek veral by die Piëtiste besware. Dit is Baumgarten wat met sy praktiese intellektualisme die oorgang van Piëtisme na Rasionalisme voorberei, waarin hy die teologie op die basis van die nuwe wetenskaplike wêreldbeskouing plaas (Wolff 1965). Hy gaan egter nie ten volle op die Wolffiaanse weg nie, maar volgens Weber is hy 'n voorstander van 'n gematigde supranaturalisme (Weber 1988:131). In teenstelling met Canz en Carpov het Baumgarten egter in die historiese belanggestel (Barth 1946:139).

Baumgarten was sedert 1734 professor in Halle en hier ontmoet Semler vir Baumgarten. Dit was veral tydens die wintersemester van 1744/45 toe Semler, Baumgarten se lesings bygewoon het, dat die band tussen die twee geleerdes verstewig word. Hier het Semler sy bevryding uit die Piëtisme ervaar en verklaar hy in Lebensbeschreibung von ihm selbst abgefasst (1781):

Ich fülete gleich einen ganz besondern Hang zu dem wirklich grossen Charakter dieses Mannes, und wir ersonnen viele Gelegenheiten, um ihn oft sprechen zu können ... Meine Blike waren gleichsam in seine Augen geheftet, so oft sie auch ehrerbietig sich wieder zurükzogen. Der vortrag erfüllete uns mit ganz andern Empfindungen über so viel sachen, wenn gleich unsre Liebe zu Knapp nicht abnam, dem wir wieder eine wahre seelengrösse in ander Absicht zutheilten.

(Semler, in Hess 1974:265)

As student het Semler in Baumgarten se huis ingewoon en was hy verantwoordelik vir die onderrig van Baumgarten se kinders (Hess 1974:21). Reeds vroeg het Semler in geskiedenis begin belangstel en in Altdorf doen Semler navorsing oor die Ryksgeskiedenis en lees ook Christoph August Hermann se Historiam Litterariam - sodoende verdiep hy sy studie in die geskiedenis (Hess 1974:346). Hy het reeds as student in Halle deel aan die Duitse publikasie, Allgemeinen Welthistorie. 
Behalwe Baumgarten het Hofrat Lenz in Halle ook 'n blywende invloed op Semler reeds tydens sy studentejare uitgeoefen en sy belangstelling in geskiedenis gewek en bevorder (Hess 1974:266). Semler dui voortdurend die veelvoudige nut van historiese kennis vir die teologie en religie aan. Die geskiedenis dui die veranderinge in die voorstellings, gedagtes en gewaarwording van mense aan en '... vermag von der vorhersscahft einzelner Doktrinen zu einer eigenen, individuelle Einsicht zu befreien' (Hess 1974:137). Volgens Stoop (1973:27) breek hy met die idealisering van die vroeëChristendom of enige ander tydvakke in die geskiedenis en sy insig is dat geen tydperk uit die verlede gesag kan dra oor die hede nie. Elke tydperk het sy eie karakter wat afsonderlik beoordeel moet word. In 1777 volg Semler vir Baumgarten na met sy boek Versuch einer freiern Lehrart wat varieer tussen die moralisme van sy eie benadering en historiese positivisme wat hy nie wou opgee nie (Weber 1988:131). Teenoor die Piëtisme en in navolging van Baumgarten stel Semler 'n teologiese wetenskapbegrip daar wat begrond is in 'n sekulariserende kennisbegrip en wat die onderskeid tussen ware en lewende insig bepaal (Hess 1974:8). Tog het Semler volgens Hess 'n teologies begronde begrip van geskiedenis. In 1760 verklaar Semler in 'n voorrede van Uebersetzung der Algemeinen Welthistorie:

Gott, der nicht umsonst die Geschichte älterer Zeiten für uns hat aufbehalten und zu unsern Zeiten zehr aufklären lassen, tat dies in der Absicht, damit auch alle historische Erkentnis immer mehr aufwachse und als ein sehr gutes Mittel zur immer gewissen Ausbesserung und wirklichen Nutzung nachdenkender Christen sich bewäre.

(Semler, in Hess 1974:137)

Op grond hiervan verklaar Hess (1974:137) dat dit nie betwyfel kan word dat God die Here van die geskiedenis is nie. Die religieuse uitleg van geskiedenis is die diepste begronding waarmee Semler sy belang in die geskiedenis teologies legitimeer. Semler begrond egter nie sy belang in die geskiedenis vanuit hierdie teologiese vertrekpunt nie, maar dit is vanuit 'n sekulêre geskiedbeskouing dat hy 'n teologiese begronding aflei, 'n geskiedbeskouing wat sy ontstaan en vorming in die opkoms van die historiese denke vind.

\section{HISTORIESE DENKE}

Die historiese denke openbaar ' $n$ bewuswording van die historiese aspek van persone en gebeure. Die kenmerkende van die historiese denke is onder andere die beskouing dat situasies in die gang van die mensheidsgeskiedenis uniek en onherhaalbaar is. Daarmee 
saam word geoordeel dat die waarde en waarheid van gebeure relatief is ten opsigte van die spesifieke historiese omstandighede van die skrywer. Verder vorm die rede die norm van ondersoek en enige uitspraak op grond van gesagsinstellings word ontken. Dit is die historiese aspek wat in die historisme opgeneem word en tot absolute norm verhoog word. Klapwijk verklaar dat die historisme die historiese denke en historiese lewensinterpretasie tot troon verhef en die historisme laat ook diep spore in die teologie, veral die hermeneutiese problematiek waarmee taalwetenskap en geskiedeniswetenskap gekonfronteer word (Klapwijk 1933:1).

\subsection{Historiese denke en historisme}

Semler as voorloper van die historisme kan nie los van die opkoms van die historisme beoordeel word nie (vgl Meinecke 1958:286). Die begrip historisme is egter volgens Dreyer, problematịes:

Wat die verwarring nog groter maak, is dat die term feitlik in elke vakgebied van die geesteswetenskappe aangewend word en hiervolgens allerlei nuanseringe aanneem. Al na gelang 'n skrywer uit die psigologie, filosofie, teologie, geskiedswetenskap en wat nog meer sake benader, verskil die betekenis van die term. Ten spyte van die feit dat die woord waarskynlik op 'n ander as die geskiedswetenskaplike terrein begin sirkuleer het, en op al die verskillende terreine aangetref word, staan dit tog vas dat ons met die term Historisme in die eerste plek en baie fundamenteel in die probleme van die geskiedeniswetenskap, meer spesifiek die filosofie van die geskiedenis staan.

(Dreyer 1958:13)

Volgens Van Jaarsveld (1980:8) beteken Historisme in teenstelling tot die naturalisme 'n wêreldbeskouing wat die mens, sy geestesontwikkeling en sy kultuurskeppinge in die middelpunt stel in plaas van die natuur, dit is die wêreld as historie. Dreyer dui onder andere die primaat van die individuele, die dinamiese in die geskiedenis en relatiwisme aan as kenmerke van die historisme (Dreyer 1958:15, 16). By Semler is die gedagte van die individuele invloed veral prominent soos hy ook verklaar: 'Jeder vernünftige Mensch, wenn er so glüklich wird, seine Seelenkräfte selbst ernstliçh anzuwenden, hat es frei, ja er hat ez zur werklichen Pflicht, ohne alle Menschenfurcht selbst hierüber zu urteilen' (Semler 1967:47). Stoop verklaar ten opsigte van laasgenoemde dat '... Semler se geskiedbeskouing berus veral op sy beskouing van die individu se beskouings 
teenoor enige idee van kerkleer wat vir alle tye geldig is' (Stoop 1973:29). Die primaat van die individuele gee verder aanleiding tot die dinamisering van die geskiedenis, want tot die wese van die individuele behoort ook verandering (Dreyer 1958:17) en Semler beklemtoon baie sterk die idee van verandering in die geskiedenis (Stoop 1973: 30). Semler kan dus nie anders gesien word as 'n voorloper van die historisme nie en volgens Meinecke se indeling van sy werk, reken hy Semler as deel van die Duitse beweging van die historisme. Ook Lee kategoriseer Semler as 'n stroom in die Duitse rasionalisme: 'To put it more precisely, the German rationalism resolved to adopt historical criticism as their legitimate principle of biblical hermeneutics; under the aegis of a synthesis of revelation and reason in the notion of a rational religion and in a view of history as the inspired moral development of mankind' (Lee 1992:15).

Die Duitse beweging moet onderskei word van die Franse geskiedenisdenke en die Engelse Deïsme (Meinecke 1959:285). Wanneer die Duitse beweging in oënskou geneem word, onderskei Meinecke twee groepe. Die een groep berei die historisme voor terwyl die ander groep die vroeë historisme min of meer uitbeeld. Lessing, Winkelmann, Schiller en Kant behoort tot die eerste groep, terwyl Moser, Herder en Goethe tot die tweede groep behoort (Meinecke 1959:287). Die historisme het dus sy oorsprong in die agtiende eeu en in die negentiende eeu ontwikkel dit tot 'n wetenskaplike, teologiese metode wat as metode onafhanklik geraak het van ander geestestrominge van die Verligting. Die historisme het mens en kultuur gaan plaas '.. op de meetlat van de tijd, in het alomvattende perspektief van geschiedenis, maakt het eo ipso iedere opvatting, elke norm en overtuiging, hoe vast ook geloofd, hoe vurig ook beleden, tot een tijdelijk verschijnsel, een voorbijgaand gebeuren' (Klapwijk 1933:3). Alles is histories en alles word dus gerelativeer. Ook Schulze is van mening dat die historiese denke die insig na vore bring dat dogmas uit bepaalde situasies gegroei het. Die historiese situasie was uniek en onherhaalbaar, dus is dogmas histories toevallig soos alle ander dinge in die wêreld. Hy verklaar ook verder: 'Hierdie insig het nie buite nie maar binne die kerk ontstaan' (Schulze 1988:7). Volgens Schulze het Luther die eerste stap in die rigting gegee toe hy gestel het dat dogmas binne konteks van die tyd waarin hulle ontstaan het, verstaan moet word. Klapwijk dui egter aan dat die voorgeskiedenis van historisme wortel in die Renaissance en vandaar word beweeg na die Verligting, Kant en die Romantiek (Klapwijk 1933:6).

\subsection{Renaissance en historiese denke}

Die opkoms van die historiese denke kan nie in die Reformasie begrond word nie, maar is in die Renaissance gewortel. Klapwijk dui aan dat die Renaisance 'n sekulêre, maar ook godsdienstig-geestelike vernuwingsbeweging is (Klapwijk 1933:6). Hierdie wêreldlike en geestelike aspek vind ons ook in die definisie van Niebuhr: 
Het gaat de Renaissance om der vervulling van het menselijke leven, maar dan niet een vervulling in een jenseitige en eschatologische toekomst, maar een vervulling hier en nu, tijdens het historische proces. De renaissancistische geloof in der vervulling en volheid des levens tijdens het historische proces wordt volgens Niebuhr door twee bronnen gevoed: door het vertrouwen der klassieke oudheid in de menslijke mogelijkheden en capaciteiten en door de bijbels-Christelijke aandrang tot heiliging en zodoende tot vervulling des levens, meer in het bijzonder de bijbel-eschatologische verwachting van de vervulling der geschiedenis zelf.

(Van Niftrik 1966:66)

Alhoewel die Reformasie ook die Middeleeuse Katolieke denke gekritiseer het, was beide teosentries gerig en afkerig van die immanente, antroposentriese outonomieideale waarvan die Renaissance en ook die historisme vervul was. In die Renaissance. is die ideaal van die homo universale: '... en de mens moet zich vrij maken van alle, wesensvreemde, outoritatiewe en bovennatuurlijke bindingen' (Klapwijk 1933:7). Dit impliseer die afwesigheid van gesag en die kerklike juk. Dit handel oor die wedergeboorte van die mens. So verklaar Van Itterzon \& Nauta (1963:142) dat die kenmerkende van die Renaissance die strewe na outonomie was en dat die mens nie langer onvoorwaardelik gesagsinstellings van buite wil gehoorsaam nie, veral nie kerklike gesagstrukture van die verlede en die hede nie.

Die erkenning van die historiese aspek word met die opkoms van die historiese denke en die Verligting die afdoende verklaring van sekere aspekte. Die historiese aspek wat in die Renaissance ontdek word, word in die Verligting verder uitgebou. Volgens Klapwijk (1933:18) is die agtiende eeu dié eeu waarin die Renaissance ideaal van die outonome mens oorgaan op die breëre massa. Lee (1992:6) is dit eens met Klapwijk dat die Verligting 'n uitvloeisel is van die sestiende-eeuse Renaissance humanisme. Ook Weber verklaar dat die Verligting se wortels in die Renaissance. gesetel is (Weber 1988:128). Vir die Renaissance en humanisme gaan dit om die mens, sy gawes, ontplooiing en heerlikheid. Alhoewel die Renaissance hom beperk tot. die geleerdes is dit uiteindelik die Verligting wat deurdring na die man in die straat.

Die Renaissance en humanisme gryp terug na die antieke kultuurwêreld en -norme van wat werklik mens en menslik was. Die Verligting daarenteen gryp vooruit na die toekoms om, uit die rede, radikale hervorming teweeg te bring (Itterzon \& Nauta 1964: 5). Kant (1724-1804) definieer die Verligting as die mens se ontwaking uit sy onmon- 
digheid deur sy rede te gebruik sonder om na eksterne gesag of leiding van iets of iemand te vra nie. Die rede oordeel oor die waarheid en die valsheid. Teenoor die Verligting erken die Rooms-Katolieke Kerk egter die gesag van die kerk en die Reformasie erken die gesag van die Skrif.

\subsection{Verligting en historiese denke}

Die omvang en grense van die Verligting is moeilik bepaalbaar. Tog het die Verligting sekulariserende tendense ten opsigte van kerkgeskiedenis en openbaringsgeskiedenis meegebring: ' $\mathrm{Zij}$ beoordeelt de historia sacra, de historia ecclesiastica, de bijzondere openbaring en alle probleemen van metafysische aard op intellektualistische wijze en tracht ze op de gemeenschapplijke noemer van het natuurlijke, rationele, algemene verklarende te brengen' (Bakhuizen \& Van den Brink 1964:28). Sonder die sekularisering van opvoeding en sonder 'n kritiese perspektief op die tradisionele onderrig van die kerk sou dit onmoontlik wees om die geskiedenis krities te beskou. Volgens Lohse is die Verligting en historiese denke nie identies nie en word dit duidelik in twee prominente manne, naamlik Semler en Lessing. Albei dra by tot die oorwinning van die historiese denke in die sfeer van die teologie (Lohse 1985:225).

Dit was die Verligting wat deels verantwoordelik was vir die opkoms van die historiese denke. Weber (1988:128) dui aan dat historiese horisonne verbreed met die uitbreiding van die natuurlike wêreld tydens die Verligting en dat die uniekheid van die Christendom in die proses bevraagteken word, alhoewel dit steeds as die hoogste godsdiens beskou word. Die historici van die Verligting (Voltaire 1697-1778, Gibbon 1737-1794 \& Condorcet 1843-1794) se geskiedbeskouing is op die idee van universaliteit en die vooruitgangsgedagte gebaseer. Hulle geskiedbeskouing is verder kosmopolities en veronderstel metafisiese abstraksie:

Die vernuf, verstand of rede geld altyd en oral vir 'n abstrakte mensheid; teoretiese konstruksies is dus belangrik. Hulle is blind vir die verskille tussen volke en tye, almal is gelyke abstrakte, matematiese groothede, altyd en oral dieselfde. Ook waardes is tydloos en geld oral. Die klem val op die algemeen menslike en generalisasie, teorieë en hipoteses. Die historici van die Verligting sien geskiedenis as regter, 'n leermeester; hulle oordeel die verlede, volke en tye met die maatstaf van die redelikheid van hul eietydse waardes en wil uit die geskiedenis leer om foute te vermy en ' $n$ beter redeliker toekoms te skep.

(Van Jaarsveld 1980:7) 
Die vooruitgangsgedagte in die Verligting word ook by Semler gevind en volgens Hornig (1975:381) dui dit op 'n ommeswaai in die protestantse teologie:

Denn die altprotestantische Auffassung von der baldigen Vernichtung des Kosmos und dem bevorstehenden Ende der Menscheitsgeschichte ist in der Aufklärungstheologie fast völlig verblaßt und weitgehend ersetz worden durch die optimistische Hoffnung auf einen unendlichen Geschichtsprosess, der zugleich mit dem allgemeinen Erkenntnisfortschritt auch eine zunehmende Vervollkommnung des Christentums bringen wird.

Semler se waardering van die wêreld- en algemene geskiedenis, sy beklemtoning van die individu in sy historiese situasie en die verdere ontplooiing van die geskiedenis dui op die invloed van die Renaissance denke. Wanneer Semler die rede van die individu aanneem as kriterium vir die historiese ondersoek, is ook die invloed van die Verligting duidelik. Kenmerkend van die Verligting is die sekulêre wêreldperspektief en die norm van die rede. Dit is veral die norm van die rede wat voortdurend by Semler voorkom. So verklaar Semler (1967:14) in Abhandlung von freier Untersuchung des Canon (1771-1775): 'Es wird vorausgesetzt dass ein Mensch sich in Ansehung seiner Seelenkräfte in der Lage befindet, selbst nachzudenken und eine Vorstellung ihrem Inhalt nach zu kennen und zu beurteilen, ob sie sich in dem vollständigen Verhältnis befindet gegen die Gründe, die ihren Beweis und ihre innere Wahrheit enthalten sollen'.

Itterzon \& Nauta (1964:19) gaan verder wanneer hulle stel dat die rede die beslissende norm word. Die rede bepaal dus wat en wat nie uit die Bybel aanvaar word. Lee beweer dat Rene Descartes (1596-1650) verantwoordelik is vir dié basiese kritiese beginsel wat op die vlak van filosofie en wetenskap heers en dat hierdie beginsel van Descartes oorgedra word na die historiografie. Die agtiende-eeuse historici aanvaar dat alle historiese materiaal betwyfelbaar is totdat dit geverifieer kan word (Lee 1992:7). Die Verligtings-kritici is gestimuleer deur die voorbeeld van die Renaissance. Laasgenoemde het die klassieke teks en 'n kritiese sin van historiografie ontwikkel deur hulle hantering van historiese dokumente. Lee (1992:8) dui aan dat wanneer agtiende eeuse historici die Bybel as historiese dokument hanteer, dit soos enige ander menslike dokument vanuit die verlede gehanteer moet word.

\subsubsection{Gottfried Wilhelm Leibniz (1646-1716)}

In Duitsland was Gottfried Wilhelm Leibniz (1646-1716) die verteenwoordiger van die Verligting en Meinecke (1959:30) verklaar: 


\begin{abstract}
Aber was uns hier vor allem angeht: In ihn steckte ein epochmachender und entwicklungsfähiger, über alles naturrechtliche Denken hinausführender Keim, der später im Historismus aufgehen sollte: die Idee der eigenartigen, spontan nach, eigenen Gesetze wirkenden und sich entwickelnden Individualität, die doch dabei die Abwandlung einer universalen Gezetlichkeit ist.
\end{abstract}

Leibniz glo verder aan die voortgang van die mensdom na vervolmaking (Meinecke 1959:43). Hierdie vervolmakingsproses bly egter 'n ewige proses. Leibniz wou 'n sintese tussen die nuwe wysbegeerte en die resultate van natuur-ondersoek met die Christelike geloof tot stand bring. Vanuit veral Leibniz se evolusionistiese-metafisiese sisteem het die Verligtingsdenke meermale geskiedenis oorskat en geskiedenis gesien as opgang na grypbare volkomenheid (Turgot, Condorcet, Lessing) of geskiedenis as voortgaande dwaling (Voltaire). Volgens Klapwijk (1933:27, 31) beskou die historici van die Verligting geskiedenis as die volbringing van die verborge plan van die natuur en die ontplooiing van elke natuuraanleg '... in de richting van het rijk der vrijheid'.

Die natuurlike samelewingsvorme ontwikkel doelgerig tot 'n sedelike geheel. In die nastreef van maatskappyvernuwing was daar ' $n$ behoefte aan 'n duidelike waardepatroon. Heilige of goddelike gewaande gesagsinstellings is wankelrig; daarom is nuwe maatstawwe en strukture noodsaaklik wat mens uit die rede kan aflei. Spoedig het geskiedeniswetenskap 'n kultuurkritiese funksie en volgens Klapwijk moes geskiedenis die menslike oorsprong en suiwer menslike gesag ontgin, dwaling en bygeloof moes veroordeel word en 'de modegevende sporen van kritisch redegebruik in de geskiedenis signaleren en de onstuitbare opgang naar de verlichte lewe traceren' (Klapwijk 1933:20). Deur natuurlike, historiese verklaringswyses en godsdienshistoriese vergelykings word die Christendom van bonatuurlike oorsprong en ook van geestelike en semi-wêreldse gesag beroof. In Semler vind ons dié kritiese gees wat op die kerkgeskiedenis van toepassing gemaak word. Aan die hand van die middels van die historiese kennis wou hy die teologie krities ondersoek en vernuwe en hy kan beskryf word as 'n teologiese rewolusionêr. In hom ontwaak die gees wat alles wil betwyfel (Stoop 1973:26). Dit was Leibniz en Christiaan Wolff se filosofie wat as brug dien tussen die Piëtisme en natuurlike verligte (Weber 1988:130). Semler het midde hierdie denk- en leefwêreld met die Piëtisme en Ortodoksie in stryd gekom.

\title{
3.3.2 Piëtisme
}

Teenoor die verheerliking van die rede beklemtoon die Piëtisme die hart en gevoel. Semler se vader het na die dood van sy vrou meer na die Saalfeldse Piëtisme geneig, soos dit vergestalt is in die persone van Lindner en Muthan wat in 1737/38 in Saalfeld 
aankom. Moontlik was die toenadering vanweë voortdurende finansiële probleme. Semler se vader het gehoop op finansiële ondersteuning van die hertog vir sy seun se studie. Uit 'kindlicher hochachtung' vir sy vader besoek Semler die gebeds- en afsonderingsure. Semler verklaar self in Lebensbeschreibung von ihm selbst abgefasst (1781): 'Es hies, der Hof seie gar nich gleichgultig, dass ein Sohn des Archdiaconus unbekehrt seyn en bleiben wolle, und durch dis Beispiel so viel andre Schüler immer mehr verderben helfe' (Semler, in Hess 1974:268). Alhoewel Semler hom langsamerhand tot die nuwe vroomheid wend, bly dit vir hom iets uiterlik, terwyl hy nie die sekerheid van die sogenaamde verseëling ervaar nie. Semler verklaar self:

Da ich nich heucheln konte, so suchte ich nun mit allen Ernst die so genannte Versiegelung und die gewisheit, dass ich ein Kind Gottes, in welcher besondern Bedeutung wuste ich freilich nich, worden seye. Kein winkel in Hause war übrig, wo ich nicht, um gewis allein und unbemerkt zu seyn, oft geknieet und viele Thräne geweinet habe; Gott möge mich dieser grossen Gnade würdigen; allein nun felete mir das, was jene Glauben nanten; nun solte ich den Schlus gleich gemacht, und mich selbst durch grosse Gedanken für alles das angesehen haben, was jene so leicht redeten. Ich blieb also unter dem Gesetz, in einem gezetzlichen Zustande wie es hiesse.

(Semler, in Hess 1974:261)

Die Saalfeldse Piëtisme maak 'n negatiewe indruk op Semler, want die strewe na kennis en wete word as sondebevlekte daad veroordeel (vgl Hess 1974:14). Hornig stel ook vas dat Semler se aandrang op eie histories-kritiese skrifuitleg teen die spiritualistiese, mistiese en afsonderingsskrifuitleg van die navolgers van die Piëtisme in sy tyd gerig was (Hess 1974:27). Reeds as student het Semler in 'n Latynse opstel aan sy vader die gedrag van sy Piëtistiese medestudente veroordeel. So verklaar hy in Lebensbeschreibung von ihm selbst abgefasst (1781):

Ich übergab meinem Vater einen lateinischen Aufsatz, darin ich meinen schuldigen Gehorsam und jene glückliche Zeit anfürte, da ich sein Wohlgefallen verdient hätte; dass ich in den Umständen meines Bruders (der jetz noch lebte) wenig Motiven fände, zu einer eben so unrichtigen Gemütsfassung; dass ich an den so sehr gelobten Schülem, theils wirkliche moralische Unordnungen sähe, folglich man mit der aüsserlichen 
Heucheley zufrieden wäre, und dass könte unmöglich eine Kraft der Gotseligkeit heissen; the ils wären die meisten Schüler Ignoranten und liebten eine solche Studenarbeit, weil sie viel leichter wäre, als sich im studieren selbst angreiffen.

(Semler, in Hess 1974:262)

Dit is veral die geringskatting van die geleerdheid en die daarmee verbonde gebrekkige kultivering van die verstand, wat Semler se renons uitlok. Later verander hy sy vooroordeel en verklaar in Lebensbeschreibung von ihm selbst abgefasst (1781):

Von den vielen separatistischen, fanatischen, mystischen Schriften, habe ich längere Zeit die gemeinern Urtheile fortgesetz und beibehalten; erst ziemlich spät wendete ich einige Zeit besonders darauf, sie selbst mit Aufmerksamkeit zu lesen; und habe freilich sie alsdenn auch viel gelinder beurtheilt; von dem ehrlichen Schwenkfeld an.

(Semler, in Hess 1974:283)

Ten spyte van Semler se stryd teen die Piëtiste se idealisering van die Oerchristendom het hy tog met agting van Spener gepraat. Hy het hom veral geskaar by Spener se hoop op die toekoms van die kerk of die Christendom (vgl Semler, in Hornig 1975: 388). Volgens Hess hou die ommeswaai verband met Semler se skeiding tussen openlike en private religie, tussen historiese en praktiese godsdiens en tussen die doel van teologie en die funksie van eie morele religie (Hess 1974:284). Semler se ommeswaai moet egter ook gesien word teen die-agtergrond van sy stryd teen die Ortodoksie.

\subsubsection{Ortodoksie}

Die jare 1760-1780 kenmerk ' $n$ fase in Semler se lewe waartydens hy hom teenoor die Ortodoksie afgrens en verklaar Hess: 'In dieser zeit kommte es zur Ausbildung eines geschichtlichen Verständnis von Theologie. Theologie, die dem wunder der zeiten unterworfen is, wurd von der unveränderlichen Religion unterscheiden' (Hess 1974:9). Met die begrip 'ortodoksie' verbind Semler nog nie die voorstelling van 'n afgeronde teologies-historiese epog nie, veelmeer dui hy met die begrip 'ortodoksie' op 'n geesteshouding en denkwyse. Semler verstaan 'ortodoksie' as fiksering van kerklike konfessie en leer. Hess sê dat Semler: '... versteht unter der orthodoxen Denkungsart, deren Schibboleth die "eine Lehre" ist, ein streben nach kirchlicher Uniformität und ein blosses festhalten und Rekapituliëren überlieferter Lehrmeinungen' (Hess 1974: 
123). Daarteenoor eis Semler vrye denke soos duidelik is uit die titel van sy werk Abhandlung von freier Untersuchung des Canons (1771-1775). Bakhuizen van den Brink (1968:83) verklaar ondermeer dat Semler ' $n$ beperkte opvatting van die leer oor inspirasie het en dat hy voorstander was van liberalis theologia en liberalis interpretatio. Hy bring Erasmus op die voorgrond en beklemtoon in die Christendom dit wat tot ons morele verbetering dien. Semler se postulaat van ' $\mathrm{n}$ freiern theologischen Lehrart het hom die verset van sy tydgenote in die Ortodoksie op die hals gehaal. Hierdie postulaat van ' $\mathrm{n}$ vrye denke impliseer dat nie net die vorm van die teologiese leer nie, maar ook die inhoud aan alle voorwaardes van die geskiedenis en individuele geleerdheid en daarom aan ' $n$ voortdurende verandering onderworpe was. Hiervan sê Hess:

\begin{abstract}
Die orthodoxe Anspruch, die reine Lehre zu bewahren, macht sich nich nur der Geschichtsvergessenheit schuldig; durch ihn werden auch Theologie und religion vermengt; weil die in einem theologischen Kompendium dargestellten Lehren, die immer Ausdruck der Lehrart eines bestimmten Theologen zu einer bestimmten Zeit sind, mit den unveränderlichen Wahrheiten der christlichen Religion identifiziert werden
\end{abstract}

(Hess 1974:124)

Dit is duidelik dat Semler se historiese begrip van teologie sy ontstaan in sy historiese begrip van die Heilige Skrif vind. Sy historiese begrip van die Skrif word egter deels gevorm deur die insigte van die Engelse Deisme.

\title{
3.4 Engelse Deïsme en historiese denke
}

Die Engelse Deïstiese literatuur word net voor die middel van die agtiende eeu in Duitsland bekend. Reeds van 1740 af kan van ' $n$ Verligtingsfilosofie in Duitsland gepraat word:

Die von nun an für etwa eine Generation herrschende theologische Schule, die Neologie, war dadurch gekennzeichnet, dass zie, z.T. unter dem Einfluss Wolffs, die Voraussetzungen und Methoden des neuen Denkens auch für die Arbeit der christlichen Theologie als geeignet $\mathrm{zu}$ akzeptieren bereit war. Die wichtigste Leistung dieser Schule war ihre kritische Bibelforschung. Sie nahm Elemente des aufklärerischen Ge- 
schichtsdenkens auf, wenn sie die Frage stellte, was in der Heiligen Schrift vergänglich, was bleibend bedeutsam sei.

(Moeller 1979:319)

Kraus (1956:83) verklaar aangaande die invloed van die Engelse Deïsme:

Die Überspülung des deutschen Geisteslebens durch die Flut der Aufklärung führte auch die Welle deistischer Natur- und Religionserkenntnis heran ... Begriffe wie 'Natur' und 'Religion' kehrte in ihrem deistischen Sinngehalt und wurde alsbald zu bestimmenden Gesichspunkten des gesamten Shriftverständnisses. Indem das protestantische Schriftprinzipen zerfällt, kehrt die natürliche Theologie ein und relativiert die biblische Offenbarung. Die Scheidewand zwischen dem alttestamentlichen Heilsgeschehén und der natürlichen Religion wird eingerissen.

Volgens Lee was dit die Engelse Deïsme wat eerste die moderne historiese kritiek in die Christelike teologie ingebring het. Die basiese leerstelling van die Engelse Deïsme is: die rede is die bron van alle waarheid. In Engeland het die Verligting ' $n$ wysbegeerte ontwikkel waarin geleer word dat alle kennis uit ervaring en waarneming stam. Die totale mensewêreld word onderwerp aan die metodes van die rede. Deur wiskundige logiese berekeninge word natuurwette vasgestel. Die metode waardeur die natuur ontleed is, word toegepas op die gebied van die wysbegeerte, godsdiens, sielslewe en mensegemeenskap. Gevolglik word die gesag van die kerk en die Skrif opsy gestoot en vind die mens die waarheid wanneer die geskiedenis vanuit en deur die rede beheer word.

In Engeland stel die Deïsme 'n natuurlike religie daar; dus een oorspronklike godsdiens waarop alle ander godsdienste teruggaan. Die Christendom in kern is gelyk aan die natuurlike religie. Matthew Tindal (1656-1733) stel dit ook in die titel van sy boek in Christianity as old as the creation, or the Gospel a reduplication of the religion of nature (1730). Jesus het niks anders gedoen as om die natuurlike religie wat reeds by die skepping in die mens geplaas is, te hernu nie (Van Itterzon \& Nauta 1964:13).

Semler beroep hom op Henry St John Bolingbroke se Letters in the study and the use of history. Bolingbroke se werk handel in die formaat van vyf briewe oor die '... notwendigkeit der gründlichen Kenntnis der Geschichte für einen Gottesgelehrten' (Hess 1974:134). Bolingbroke beveg as Deïs die Engelse ortodokse teologie en volgens Strauss (1984:12) het Bolingbroke saam met John Toland (1670-1722) die Bybel 
beskou as versameling onegte en fabelagtige boeke. Alhoewel Semler die insigte van Bolingbroke waardeer, bestry hy nogtans die wyse waarop Bolingbroke dit gebruik. Aangaande die invloed van die Engelse Deisme, dui Hess (1974:347) ondermeer aan dat Hettner in sy Geschichte der deutschen Literatur im achtzehnten Jahrthundert, 3 Teil 2 die Engelse Deisme as bron vir Semler se denke beskou en Hettner meen verder. dat veral John Locke (1632-1704) se boek, Reasonableness of Christianity en Toland se Christianity not mysterious ' $n$ invloed op Semler se denke gehad het. Volgens Hess beaam Gastrow Semler se verhouding tot die Engelse Deisme in sy werk van 1905 Joh Salomo Semler in seiner Bedeutung für die Theologie, Griessen (Hess 1974:347). Toland staan ' $n$ hermeneutiese beginsel, wat die ruggraat vorm vir historiese kritiek van die Bybel voor: ' $\ldots$ all the doctrines and precepts of the NT must consequently agree with natural reason, and our own ordinary ideas ....' (Lee 1992:10). Teenoor die Christelike-perspektief wat impliseer dat die rede ondergeskik is aan die openbaring, beskou Toland die rede as kritiese maatstaf van die openbaring. Volgens Lee (1992: 12) verwerp ook David Hume wonderwerke en die besondere openbaring. Hume verwerp so uiteindelik ook die aanspraak dat die Skrif 'n geinspireerde openbaring van God is en stel Lee verder dat as toegegee word aan Hume se anti-wonder vooronderstelling, dan kan nóg die Bybel nóg enige ander gebeure aan 'n Goddelike openbaring toegeskryf word en is ook die historisiteit van die opstanding van Jesus Christus onder verdenking (Lee 1992:13). Toe Hume moraliteit begrond het in spesifieke morele gevoelens en oordeel, het hy bygedra tot die ontwaking van historiese denke. Hume bied in der waarheid ' $n$ sosiologiese en etiese analise van etiek. Hy het verder ook in ' $n$ kritiese historiografie, naamlik History of England, aan die geskiedenis 'n kritiese funksie toegeken (Lee 1992:14). Dit was dan ook Hume wat die idee van Verfall vervang met die konsep van ordelike ontwikkeling en voortgang in natuurlike en sosiale prosesse. In The Natural history of religion gaan hy verder. Hy analiseer die oorsprong van godsdiens krities by wyse van die evolusionistiese siening van die geskiedenis. Hy stel ondermeer dat die vroegste religie van die mensdom nie monoteisties nie, maar eerder politeisties was, wat tot ' $\mathrm{n}$ monoteïsme ontwikkel het (Lee 1992:14). Die gedagtes van die Engelse Deisme asook die Renaissance en Verligtingsdenke vloei in Semler saam en dra by tot die vorming van sy geskiedbeskouing. Kraus verklaar: 'Im 18. Jahrhundert setz sich die moderne, vom biblischen Geschichtsbild gelöoste historische Betrachtung mehr und mehr durch' en verder 'Eine Entdogmatisierung des biblischen Geschichtsbildes durch die Grundideen der Aufklärung wird gefordert' (Kraus 1956:94). 


\section{GESKIEDENIS}

\subsection{Geskiedbeskouing}

In ' $\mathrm{n}$ voorrede wat Semler skryf in Algemeinen Historie von Spanie (1757) gaan hy in op die noodsaaklikheid van die studie van geskiedenis, en die waarde en die nut van geskiedenis in die algemeen en vir die teologie in die besonder. Wat Semler van die studie van kerkgeskiedenis sê, geld ook vir die studie van geskiedenis in die algemeen. Semler in Versuch christlicher Jahrbücher, oder ausfühlicher Tabellen uber die Kirchenhistorie, Erster Theil, bis aufs Jahr 900 (1783) verklaar:

... dass es dem Menschen die ausserordentliche Wohltat einer Förderung und Vermehrung in der Erkenntnis Gottes, eigener Gottesfurcht, heilsamen und festen Vertrauens in Gott gewährt. Ich bin schon viele Jahre her davon überzeugt, dass zur gewissen und glücklichen Cultur, und eignen besten Religion der Menschen kein sicherer Weg seie, als die Ausbreitung historischer Kentnisse ... Alle meine Arbeiten, die ich als Gelehrter unternommen habe, sind historischer Art, und wenn sie einigen Nutzen schaffen, so entstund er aus der wohlthätigen Natur der Historie.

(Semler, in Hess 1974:347)

Volgens Lee (1992:17) dring Semler daarop aan dat '... one must understand the past as past ...'. Hy eis 'n kritiese begrip van die Bybel en van kerkhistoriese dokumente wat nie deur die Verligtingsdenke vervang word nie, maar in hulle historiese bepaaldheid erken moet word (Mühlenberg 1980:265). Semler stel dus nie die rede as bron van waarheid nie, maar wel die historiese konteks. Die weg na die waarheid in sy historiese verband geskied by wyse van die rede. Die verlede moes geïnterpreteer word as 'n resultaat van sosiale en historiese omstandighede wat nie meer bestaan nie en nooit sal terugkeer nie. Tog bly Semler nie staan by die historiese samehang nie, maar volgens Lee (1992:17) is daar 'n voortgang waarneembaar en verklaar Lee dat die gang van tyd as ewolusieproses beskou moet word met die etiese en religieuse vervolmaking van die mens as doel. Vanuit bogenoemde vooronderstelling maak Semler 'n onderskeid tussen godsdiens en teologie. Hagenbach (1896:1007) verklaar dat by Semler godsdiens en sedeleer (verbetering van die lewe) reeds saamval. Ook Barth (1946:148) is van mening dat 'n mens voortdurend by Semler die voorstelling van 'n wese van die Christendom vind. Dit bestaan in die gedagteverandering, dadeverbetering en hieruit 
vloeiende morele welvaart, wat alle mense toekom deur Christus en die Heilige Gees. Heil is sedelike morele besit. Hagenbach stem hiermee saam wanneer hy Semler en Lessing saam noem in Lessing se perspektief rakende die vervolmaking van die Christendom. Die begrip 'moreel' het by Semler ' $n$ ander betekenis as wat dit by hedendaagse gebruikers het. Die Verklarende Handwoordeboek van die Afrikaanse Taal verklaar 'moreel' ( $\mathrm{S}$ nw) as sedelike en geestelike krag wat mense vol moed en geesdrif laat bly. As byvoeglike naamwoord en bywoord dui dit op die gevoel vir wat goed en reg is; sedelik (HAT 1994). Hirsch verklaar egter: 'moralisch hat bei Semler wie meist in seiner Zeit einen andern Sinn als heute. Es steht im Gegensatz zu physisch. Die physische Welt is das Reich der Natur, die moralische das Geisterreich; die Gottestadt im Sinne Leibniz' (Hirsch, in Semler 1967:5). Ook Hornig dui verder aan dat die begrip moralischen Religion nie op 'n rasionalisme of verstandschristendom dui, of enigsins iets te doen het met ' $n$ moralisme of met beperkte Christelike handeling nie, maar: 'Die sich in einem unendlichen Entwicklungprozess vollziehende Vervollkommnung des Christentums ist für ihn vielmehr die Entfaltung des soteriologischen Gehalts der Christusbotschaft' (Hornig 1975:389). In sy onderskeid tussen Woord van God en Bybel, maar ook sy onderskeid tussen teologie en godsdiens, moes Semler ook onderskei tussen '... substance of the message, the essential truth, from the original historical accidentals of the Bible by way of the historical-critical method ...' (Lee 1992:17). Hierdie onderskeid lei noodwendig na 'n onderskeid in kerkbegrip.

\subsection{Kerkbegrip}

Behalwe sy onderskeid tussen teologie en godsdiens, onderskei hy ook tussen interne en eksterne godsdiens. By Semler vind ons egter nie 'n duidelike definisie van sy kerkbegrip nie. Hierdie vaagheid rondom die kerkbegrip is te wyte aan die oplossing van die kerk en die Christendom in die individu. Barth is van mening dat die Christendom vir Semler ' $n$ bepalende en medebepaalde grootheid van die geskiedenis is (Barth 1946: 148). Lee verklaar dat Semler die geskiedenis van die Christelke godsdiens beskou het as 'n ontwikkeling. Dié ontwikkeling het egter by wyse van 'n ewolusionêre en dialektiese tussenspel tussen interne en eksterne godsdiens ontstaan (Lee 1992:17). Van die kerk as organisatoriese grootheid is daar by Semler nie sprake nie en alles word in die individu begrond. Ook Stoop dui aan dat die kerk eerder 'n konglomerasie van individue is as die liggaam van Christus (Stoop 1973:29). Hierdie individualiserende motief vind ons, soos Hess (1974:196) aandui, veral by Semler: 
Die Offenbarung Gottes in der hl.Schrift ist für jeden Christen die Quelle und der Ursprung seiner eigenen Religion ... Jeder Christ muss für sich nach Massgabe seines Erkenntnisvermögens dieses Prinzip einer geistlichen, moralischen Religion in seiner eigenen moralischen Geschichte verwirklichen und darin über die geringen historischen Anfänge der christliche Religion, die noch mit vielen unmoralischen, nicht auf den inneren Zustand der Seele bezogenen Vorstellungen aus dem Judentum und Heidentum belastet sind, hinausschreiten.

Ook Kantzenbachs oordeel in sy werk:

Semler habe 'zur Restauration des Bekenntniskirchenideals, dem er noch, ganz verhaftet war', beigetragen, bedarf insofern einer Korrektur, als Semler später von der unterscheiding öoffentlicher und privater Religion ausgehend feststellt: ' $\mathrm{Da}$ die christlichen Religion in einer moratischen unnerlichen Fertigkeit besteht', gelte auch dass sie 'an eine sichtbare Kirche' niemalen gebunden ist.

(Kantzenbachs, in Hess 1974:352)

Selge (1982:163) dui verder aan dat Semler na die bekwame en die (nog) onbekwame mense en Christene verwys en "... wollte mit dem Recht der "Fähigen" auf Fortschritt in der Erkenntnis in Sinne der geistigen Emanzipations Bedürfnisse von Teilen des Bürgertums des 18 Jahrhunderts einen privaten Freiraum in einer öffentlich noch von Staats- und Kirchenzwang zu genormtem Traditionsbekenntnis bestimmten Wirklichkeit eröffnen'.

Die amptelike kerk bevestig dus alleen die heerskappy en gesag van die kerklike ampsdraers (Pont s a:14). Semler se kerkbegrip word gekenmerk deur die onderskeid wat hy maak tussen die private und offentlicher Religion. Terwyl die ware Christenwees in die morele, innerlike godsdiens verwerklik word en as sulks nie 'n godsdiensgemeenskap, 'n leeramp en 'n leerordening benodig nie, is die openlike godsdiens daar om die volk se wil te behou. Vir die ware innerlike Christenwees bied die Nuwe Testament net '... eine unvollkommene Anfangsgestalt Christlicher Lehre, und es die Aufgabe der Christenheit, über diese Gestalt hinauzuwachsen ...' (Waldenfels 1977:65). Die onderskeid tussen wat Semler noem die Kinder, Anfanger, ungeübte, schwache Christen en die Vollkommnere, is volgens Hornig af te lei uit Semler se onderskeiding in twee klasse in die Oerchristendom, naamlik 'n wetsstrenge Jooodse Christendom en 'n vryer Pauliniese rigting (Hornig 1975:384). Dit is vanwee Semler se onderskeid 
tussen 'n vrye privatreligion des Einzelnen en 'n Religion der Gemeinschaft mit einer durch den Staat zu garantierenden Lehrordnung dat Semler se kerkgeskiedenisbeeld mank is (Barth 1946:149). Die kerkgeskiedenis word selfs opgelos tot 'n geskiedenis van individuele persoonlikhede en die konflik tussen die individu en die openbare religie (Stoop 1973:29). Die onderskeid tussen die bekwame en onbekwame Christene kan teruggelei word na die opvoedingsgedagte of vervolmakingsgedagte wat in Semler se geskiedbeskouing heers.

\title{
4.3 Vervolmaking
}

Soos Lessing, interpreteer ook Semler die verhouding tussen openbaring en geskiedenis deur die gedagte van 'n goddelike opvoedingsplan, sodat godsdiens sy verdediging '... nicht durch ein vorgegebene, am amfang der Zeiten stehendes sein, sondern durch ihr Werden und das Ziel dieses Werdens erfährt' (Hess 1974:200).

Dit was egter Johann Lorenz von Mosheim (1694-1775) wat die Verfallstheorie verwerp en die ontwikkelingsgedagte in die teologie inlyf. Schmidt (1965:1424) verklaar dat Eusebius die voorloper van die Verfallstheorie is, deurdat hy die kerk net tot en met die tweede eeu as rein en suiwer beskou. Mosheim se geskiedbeskouing en kerkbegrip het ' $n$ duidelike invloed op Semler gehad. Soos later by Semler het Mosheim se geskiedbeskouing aanleiding gegee tot ' $n$ ander kerkbegrip. Stoop (1973:21) meld soos volg:

\begin{abstract}
Mosheim wil hê dat die historikus telkens weer sal nagaan waarom 'n bepaalde gebeurtenis plaasvind, met ander woorde, die blootlegging van die oorsake van alle gebeure vorm die historiese oordeel. Hiervoor is mensekennis nodig; alleen deur ware mensekennis kan die motiewe van menslike handelinge beskryf word. Hierdie soort geskiedskrywing staan bekend as die pragmatiese. Voor Mosheim is dit reeds in die gewone geskiedskrywing beoefen; sy prestasie was net om dit ook net by kerklike historiografie in te voer. Dit bring die omverwerping van die hele teologiese geskiedsbeskouing tot op sy tyd mee. Die verloop van die hele geskiedenis is immers tot in hierdie stadium teruggevoer tot die werksaamheid van God. Mosheim voer af en toe nog die supranaturele in, maar meesal gaan dit by hom oor natuurlike oorsake.
\end{abstract}

Aangesien Mosheim tot die Verligting behoort, verbind hy 'n etiese doelstelling met die historiese doelstelling, wat daarop dui dat die geskiedskrywer die menslike gemoed moet binnedring om vanuit dié perspektief die mens te onderrig (Stoop 1973:20). Vol- 
gens Pont (s a:14) het Semler bogenoemde gedagte verder ontwikkel. Met die gedagte van die vervolmaking van die Christendom maak Semler 'n nuwe, dinamiese en toekomsgerigte element in die teologiese geskiedbeskouing geldend. Reeds in 1771 het Semler verklaar: 'Aller Anfang bleibt Anfang und is noch nicht Vollkomenheit' (Semler, in Hornig 1975:386). In 'n brief, $D$ Joh Salom Semlers brief an einen Freund in der Schweiz über den Hirtenbrief der unbekanten Obern des Freimaurerordens alten Systems Leipzig (1786), skryf Semler: '... Immer weiter, a minor ad majus, ist Gottes moralische algemene ordnung ...' (Semler, in Hess 1974:395). Ook Semler se beskouing van tyd en ruimte en sy onderskeid tussen openbare- en privaatgodsdiens dui op die vervolmakingsgedagte. Selge (1982:135) verklaar:

... der Verzicht auf die Vorstellung von der normatieven, vorbildlichen Volkommenheit der Urchristenheit, die wahre Christliche Frommigkeit is geschichtlich wie individuell wachstumfähig und nach fülle der geschichtlichen-kulturellen situatien wandelbar und die grundsätzliche unterscheiding von Theologie und Religion.

Die vervolmakingsgedagte het gewis ' $n$ wending in die Protestantse teologie gebring. Volgens Hirsch het Semler vir die protestantime 'n nuwe lig aangesteek (vgl Hornig 1975:382). Vanweë die toepassing van die vervolmakingsgedagte en oneindigheidsgedagte op die ontplooiing van die Nuwe-Testamentiese heilsboodskap, moes ook die openbaringsbegrip gedinamiseer word. So verklaar Hornig (1975:389): '.. der Begriff der göttlichen Offenbarung mußte auf den Geschichtprosess als ganzen, auf die vergangene wie zukünftige Entwicklung des Christentums bezogen werden'. Dit het beteken dat, behalwe die Bybelse openbaring daar 'n steeds voortgaande openbaring vir die hede aangeneem moet word. Hornig verklaar verder dat God se openbaring dus nie tot vergange histories heilsgebeure beperk is of afgesluit word nie, maar eerder as ' $n$ voortgaande historiese proses beskou moet word (Hornig 1975:389). Dit impliseer dat Christus nie die finale en volkome openbaring van God was nie, maar die geskiedenisontplooiing word nou die openbaringsmiddel. Hornig verklaar egter dat die dinamisering van die openbaringsbegrip nie beteken dat die heilsgebeure in Christus gerelativeer word nie: 'Denn die Botschaft von der durch Jesus Christus bewirkten Versohnung und Erlösung soll ja gerade in ihrem Gehalt für die sich ständig verändernden Bedingungen des menschlichen Daseins enfaltet werden' (Hornig 1975:389). Semler verklaar dat die '... Vorstellung van göttlicher Offenbarung, welche freilich in den Urkunden der ersten Christen der Sache nach ganz gewiss enthalten ist, doch, nur als Anfang, als einer 
unendlich fortgehenden moralischen Schöpfung gedacht werden kann' (Semler, in Hornig 1975:389). Semler se openbaringsleer word noodwendig nou met die pneumatologie verbind. Die voortgaande openbaring van God in die geskiedenis sal as 'n werking van die Goddelike gees en as 'n vermeerdering of verdieping van Christelike geloofskennis verstaan word. Die subjek van die ontwikkeling is vir Semler dié God wat die geskiedenis aanmekaarskakel (Hornig 1975:389).

\subsection{Kanon en konfessie}

Semler se historiese ondersoek en die gedagte van vervolmaking lei hom tot kritiek en ten slotte tot prysgawe van tradisionele leersake. Vir Semler is die Christendom 'n meer volkome godsdiens as die Jodedom en die heidendom (Hornig 1975:383) en hoort die kanon tot die sfeer van openbare godsdiens soos deur die kerk bevestig en het dus geen definitiewe funksie vir private godsdiens nie. Semler verklaar in 1771:

Die Canonicität wird also in Ansehung der Clericorum oder der öffentlichen Kirchendiener, welche solche Bücher gebrauchen sollten, festge$z e t z t$, dass diese keine andern Bücher zum Vorlesen und zum verbindlichen Unterricht annehmen und einführen dürfen, als welche in dieser Kirche zu canonicis libris gerechnet wurden.

(Semler 1967:22)

Die kanon het dus 'n juridiese funksie, maar nie 'n godsdienstige funksie nie (Weber 1988:257). Vanweë die ontwikkelingsgedagte is die vroeë Christendom nog nie die finale en volkome Christendom nie en Hornig verklaar dat die oorsaak vir die onvolkomendheid van die begingestalte van die Christendom teruggelei kan word na die invloed van die kontemporêre Jodedom en heidendom se godsdienstige oortuigings (vgl Hornig 1975:384). Die teorie van die vervolmaking van die Christendom impliseer 'n relativering van die gesamentlike huidige dogmen- en teologiegeskiedenis. Hierdie relativering is veral by Semler merkbaar wanneer hy die idealisering van die oerChristendom verwerp. Hornig meld in verband met laasgenoemde: 'Damit widerspricht er der von Orthodoxie und Pietismus vertretenen Grundüberzeugung, dass das Urchristentum für alle späteren Epochen der Kirche, Theologie und Christenheid als vorbildlich und normativ zu gelten habe' (Hornig 1975:385). Semler skryf in sy werk Religion der Christen (1786) soos volg: 
Es ist ein grosser Irrtum, dass man in der katholischen Kirche es als ausgemacht eingeführt hat, die christliche Religion habe schon zu den Zeiten der Apostel oder der sogenannten ersten Christen ihre ganze je mögliche Vollkommenheit gehabt, sie müsse ebenso von allen Christen ferner nachgeamet und bloss wiederholt werden.

(Semler, in Hornig 1975:386)

Die historiese Christendom is dus nie volmaak nie, maar kan vervolmaak word. As historiese godsdiens vereis die Christendom tradisie (soos die kanon), maar tradisie moet geïnterpreteer word as die essensie van God se akkommodasie ten opsigte van ons steeds onderontwikkelde rede. Semler hanteer al die probleme wat Lessing probeer oplos, naamlik die verhouding tussen rede en geskiedenis en rede en openbaring (Weber 1988:131). Die vervolmaking van die Christendom is geen kortstondige ontwikkeling van 'n paar geslagte nie, maar 'n oneindige proses. Hierdie geleidelike vervolmaking word egter nie verstaan in die sin van voortgaande fiksering of totale dogmatisering van die kerklike leer nie en ook nie as toenemende bekragtiging van belydeniskerke nie; maar eerder as ' $n$ proses van disintegrasie van huidige, bestaande konfessionele leeruitsprake (Hornig 1975:390) en Semler bou hierin sterk op die voonitgangsgedagte van die Verligting (vgl Hornig 1975:391). Die vervolmakingsgedagte lei vanuit hierdie bodem die kerk na 'n heilstaat waar konfessie en leermatige verskille verdwyn - na 'n Christendom onafhanklik van belydenis of amp.

\subsection{Christendom}

Die historiese Christendom is nie perfek nie, maar word mettertyd perfek en '... es ist eines Wachstum seiner Vollkomenheit fähig' (Hornig 1975:386). Ook die Reformasie is net ' $n$ verdieping in die dogmenhistoriese proses. Die historiese vervolmakingsproses is nog nie deur die Reformasie tot afsluiting gebring nie en daarom verklaar Stoop (1973:28) dat Semler die idee, dat die Reformasie 'n terugkeer na die vroeëré Christendom is, verwerp. Semler kritiseer in sy werk, Ob der Geist des Widerchrist unser Zeitalter auszeiche? (1784), die Flaciaanse Luther-skolastiek wat stel dat '... die Reformation sei vollendet und man müsse bei Luthers Schriften nun stehen bleiben' (Semler, in Hornig 1975:387). Die bekwame Christene sal deur hulle logika en deur die leiding van God se voorsienigheid tot 'n verdiepte heilskennis dring. Hiervan sê Semler: 
Wir sollen ja wachsen in der erkentnis Christi und des grossen Erfolges, wozu Christus gesendet worden; wir sollen nich mit jenen Anfängem wissentlich stehen bleiben und die sich anbietende Gelegenheit $\mathrm{zu}$ weiteren Erkenntnissen oder Entwicklung und Verknüpfung derselben; als eine tägliche Wirkung der Providenz Gottes gern annehmen.

(Semler, in Hornig 1975:387)

Semler poneer die toekomstige gestalte van die Christendom as 'n universele liefdesgodsdiens, getipeer deur die gebod van liefde, sal bestaan. S6 'n vooruitskouing versterk die konfessioneel-oplossende en unionistiese tendense, want '... die noch bestehende Aufteilung der Christenheit in Konfessionskirche, die durch Lehre und Bekenntnis voneinander geschieden waren, konnte nun als bloßes Durchgangsstadium der geschichtlichen Entwicklung betrachtet werden' (Hornig 1975:391). Dieselfde gedagte vind ons ook by Semler se akkommodasie-teorie. In die akkommodasie-teorie gaan Semler van die standpunt uit dat, in die geskiedenis van Jesus en die apostels, God Homself as die eintlike bewerker van die akkommodasie bewys - dat Hy Jesus en die apostels by die voorstellings van hulle toehoorders aangepas het (Hess 1974:182). Semler sien uit die akkommodasie-teorie verdere gevolge. Semler poneer 'n voortgaande, oneindige historiese ontwikkeling, en die voortdurende toename van die Christendom se geestelike kennis (Hess 1974:184).

Wanneer na die wortel van die vervolmakingsgedagte gevra word, is dit veral by Leibniz (1646-1716) en Spener (1635-1705) te vinde. Leibniz toon weer trekke van die neo-Platonisme. Leibniz se hoop op 'n oneindige, voortgaande geestelike en morele voleinding en Spener se hoop op beter tye vir die kerk word deur Semler in die teologie ingedra (Hornig 1975:387).

Volgens Hornig (1975:391) is die inhoud van die Christelike godsdiens vir Semler ... ins Unendliche entwickeln und alsdann kan er alle einzelnen historischen Religionen in sich auflosen'. Dit is duidelik dat die toekomstige ontwikkeling nie net die integrasie van alle Christelike denominasies en belydeniskerke in die gestalte van ' $n$ bokonfessionele Christendom teweegbring nie, maar daaroor heen ook die verdere ontwikkeling van die Christendom tot 'n 'alle-mense-omvattende' universele mensheidsgodsdiens stimuleer: 'Der Entwicklungsprozess zielt auf die Verwirklichung einer Liebesreligion, die aus den Quellen der empfangenen Liebe Gottes und Gnade Christi lebt, das gegenseitige Verhalten bestimmt und alle Christen zur gemeinschaft des Heiligen Geistes zusammenschliesst' (Hornig 1975:391). 


\subsubsection{Heilsgeskiedenis}

Op grond van Hornig lyk dit asof die begrip heilsgeskiedenis nie by Semler figureer nie. Die heil is vir Semler gelee in die voortgaande openbaring van God in die geskiedenis. Pont (1978:4) stel egter dat ' $\ldots$ in die lang gang van geskiedenis is daar 'n bepaalde hoeveelheid gebeurtenisse wat eie-soortig in die geskiedenis is en dit is heilsgeskiedenis. Die geskiedenis van Jesus Christus, die Seun van God, wat mens geword het'. Ook Dreyer (1966:157) dui aan: 'Die Christelike geskiedenisvisie is dat die geskiedenis begin by die skepping en die sondeval en eindig by die wederkoms van Christus. Die inkarnasie van Christus is die middelpunt wat die geskiedenis in twee dele deel. Dit is nie 'n chronologiese middelpunt nie, maar die singewende middelpunt'.

Hornig verklaar dat Semler die Christelike geskiedbeskouing in die algemene geskiedenis begrond. Hy sê onder andere: 'Der Gedanke, dass die geschichtliche Entwicklung ein allmähliches Wachstum und eine Vervollkommnung des Christentums bringen wird, klingt in verschiedene Schriften und Versionen mehrfach an' (Hornig 1975:383). In die voortgang van die geskiedenis is God se openbaring nie beperk tot 'n afgeslote heilsgebeure in die verlede of ewig-geldend afgesluit nie, maar God se openbaring moet gesien word as 'n voortgaande oneindige historiese proses. Alhoewel Hornig stel dat die eenmalige heilsgebeure in Christus - wat as versoening en verlossing in sy lewe, sterwe en opstanding werksaam word, nie deur so 'n voortdurende en dinamiese openbaringsbegrip gerelativeer word nie, is die teendeel waar. Wanneer Semler stel dat die voorstelling van Goddelike openbaring in die bronne van die eerste Christene net as begin van 'n oneindige voortgaande morele skepping beskou te word, lewer hy daardeur die inhoud van die openbaring in Christus uit aan die geskiedbeskouing van die Verligting. Teenoor Semler se opvatting van die oneindige openbaringsproses kan Pont se siening gestel word:

Deur die heilsgeskiedenis word nog ' $n$ verdere, besondere belangrike gebeurtenis duidelik. Enersyds weet die Christengelowige dus dat die historiese gebeurtenisse rondom Jesus Christus die sentrale, dragende middelpunt van alle mensheidsgeskiedenis is. Die Christengelowige weet ook dat die geskiedenis van sy eerste begin in die skepping doelgerig voortbeweeg het na die koms van Jesus Christus. Andersyds weet die Christengelowige egter nou ook dat die geskiedenis van daardie punt af doelgerig voortbeweeg na die uiteindelike terugkeer van Jesus Christus na ons aarde.

(Pont 1978:6) 
Semler sien die vroeë Christendom as die onvolkome gestalte van godsdiens wat steeds vernuwe word. Hy beskou dus nie die openbaring in Christus as afgehandelde eenmalige en voldoende openbaring nie, maar 'n gegewe wat steeds aangepas en meer volkome openbaar word soos wat die menslike verstand in vaardigheid toeneem. Deur die heilsgeskiedenis in die geskiedenis op te los, dra Semler by tot die ontkerstening van die Christelike heilsgeskiedenis. Hierdeur pas Semler 'n filosofiese metode en geskiedbeskouing op die openbaring, kerk en teologie toe. Dit is veral die vooruitgangsgedagte van die Verligting wat Semler se geskiedbeskouing beïnloed. Vanuit hierdie vooronderstelling is daar ' $n$ voortdurende progressie in Semler se denke waarneembaar. Van Niftrik vra tereg: 'Gaat het dan eigenlijk nu wel over de vooruitgang der mensheid? Die vooruitgang is een "mythe", waardoor de geschiedenis hanteerbaar, enigermate begrijpelijk en aanvaardbaar wordt. De mensheid kan niet leven zonder zulke "mythen". Zij kan niet leven bij objectieve historische feiten alleen' (Van Niftrik 1966:8).

Die vooruitgangsgedagte veronderstel dat mens die geskiedenis soos die natuur, volgens wetmatigheid, ondersoek. Geskiedenis is egter anders as die natuur. Geskiedenis is nie 'n objek wat objektief ondersoek en beskryf kan word nie. Om die sin van geskiedenis te sien sou mens buite die geskiedenis moes staan, of die sin van geskiedenis sou aan die mens geopenbaar moes word (Van Niftrik 1966:31).

By Semler word die volgende vooronderstellings gevind:

* Die outonomiteit van die kritiese rede by die individu.

* Die relatiwistiese aard van geskiedenis.

* Die dinamisering van die openbaring.

* Die Skrif is 'n menslike boek.

Semler verklaar in sy Lebensbeschreibung von ihm selbst abgefasst (1782):

Ich liebte die Gelehrsamkeit um so mehr, als sie das einzige fast allmächtige Mittel war, eigenes Nachdenken in der Welt $\mathrm{zu}$ befeördern, welches eine unüberwindliche Kraft des gewissens mit sich bringt. - Je mehr die Grundsätze der protestantischen Kirche einem jeden Menschen diese freiheit des eigenen Denkens und Untersuchens gewähren wider die papistische vorige Lehrordnung, dass er nun selbst in seinem Gewissen es entscheiden kann: desto liebenswürdiger wurden diese Grundsätze.

(Semler, in Kraus 1956:97) 
Die een feit wat nie in aanmerking geneem is nie, is dat die interpretasie van historiese inligting bepaal word deur 'n sekere perspektief van die geskiedenis (Lee 1992:26). Semler het nie sy eie historiese vooronderstellings in ag geneem nie en vanuit sy geskiedbeskouing 'n nuwe Skrifverstaan ingelei.

\section{SAMEVATTING}

Semler se beskouing van geskiedenis, kerkgeskiedenis en heilsgeskiedenis word juis deur sy vooronderstellings gevorm. Dit is die Renaissance denke en die Verligtingsdenke in Duitsland - soos wat dit in Leibniz, Christiaan Wolff en Baumgarten vergestalt word - wat tot die vorming van Semler se geskiedbeskouing bydra. Ook die Engelse Deïsme het bygedra tot sy geskiedbeskouing en gevolglik sy Skrifverstaan. In Semler vloei dié onderskeie strome saam en word sy geskiedbeskouing die stukrag vir die ontwikkeling van die historiese kritiese ondersoek. Soos by Mosheim het Semler se historiese metode en geskiedbeskouing die kerkgeskiedenis en heilsgeskiedenis gerelativeer. Stoop verklaar ten opsigte van Mosheim:

Hoewel Mosheim self soms nog vir die kerkgeskiedenis die benamings historia sacra gebruik, is alle 'heilige geskiedenis' in werklikheid uitgeskakel. Na aanleiding van sy pragmatiese metode het daar immers 'n suiwer 'menslike' beskouingswyse van die kerkgeskiedenis begin; die stof word eenvoudig histories bemeester en die metode het totaal geseëvier oor die inhoud. Daarmee het 'n wetenskaplike behandeling van die kerkgeskiedenis 'n religieuse voorstellingswyse afgelos.

(Stoop 1973:23)

Semler bou vanuit hierdie standpunt voort. Vir hom is die geskiedenis van die kerk 'n geleidelike vervolmaking van die Christendom. In die ontwikkeling en vervolmaking sien hy die ontplooiing van die soteriologiese waarde van Christus.

Die vervolmakingsgedagte raak egter die gesamentlike geskiedenisproses, waar alle teenpole deur God in versoening gebring word. Semler se beskouing van kerkgeskiedenis word verder gekenmerk deur die onderskeid wat hy maak tussen vaardige en nievaardige Christene, tussen die oer-christendom en die toekomsgestalte van die Christendom. Hy onderskei voortdurend tussen vorm en inhoud en deur die rede kom die Christendom tot 'n steeds dieper begrip van die God se openbaring. Hierdie onderskeid is alleen moontlik vanuit ' $n$ geskiedbeskouing en metode wat met die Verligtingsdenke, en in die besonder in Wolff se filosofie sy vertrekpunt het. Dit wil sê 'n ge- 
skiedbeskouing en metode wat die teenpole - rede en openbaring, kerk en wêreld en geskiedenis en heilsgeskiedenis wil versoen. Kraus oordeel egter hierteenoor dat Semler se geskiedbeskouing gevorm word deur sy metode van ondersoek. Hy verklaar: 'Diese freiere Untersuchung, die zwischen göttlichen Inhalt und menschlicher Form der Bibel unterscheidet, führt jetzt eine historische Betrachtungsweise ein, die sich nicht nur von dem biblischen Geschichtverständnis löst, sondern die sich auch dem Kanon gegenüber kritisch durchsetzt' (Kraus 1956:98).

Alhoewel Semler dit nie so wou gehad het nie, het sy geskiedbeskouing die openbaring en teologie, kerk en belydenis uitgelewer aan die filosofie. Hornig verklaar dat dit nie Semler se bedoeling was, om Christelike geloofskennis in algemeen menslike kennis, en teologie in filosofie op te los nie: 'Aber er hat doch gegen Ende seines Lebens hervorgehoben, dass das sukzessive Wachstum in der christlichen Glaubenserkenntnis eine Parallele in dem allgemeinen menschlichen Erkentnnisfortschritt besitzt' (Hornig 1975:391). Wanneer die kerkhistorikus dus die geskiedenis van die kerk en heil binne die wêreld betrag, moet deeglik kennis geneem word van sy vooronderstellings. Tereg verklaar Butterfield: 'Amongst historians, as in other fields, the blindest of all the blind are those who are unable to examine their own presuppositions, and blithely imagine therefore that they do not possess any' (Butterfield 1954:46). Pont stel:

Dan moet verder daarmee rekening gehou word dat in die kerkgeskiedenis die voorveronderstelling nie bepaal word deur ' $n$ immanente faktor in die geskiedenis self nie, maar deur die transendente faktor - Jesus Christus, die Hoof en Heer van die Kerk, die bepalende in die Kerk, die dragende middelpunt en die finale einde van die geskiedenis.

(Pont 1963:152)

\section{Literatuurverwysings}

Barth, K 1946. Die Protestantische Theologie im 19. Jahrhundert: Ihre Vorgeschichte und ihre Geschicte. Zürich: Theologischer Verlag.

1956. Church Dogmatics. (Part 1/2). Edinburgh: T \& T Clark.

Bakhuizen van den Brink, J N \& Dankbaar, W F 1968. Handboek der Kerkgeschiedenis, vol 4. Den Haag: Bert Bakker/Daamen.

Beyreuther, E 1978. Geschichte des Pietismus. Stuttgart: J F Steinkopf Verlag.

Butterfield, H 1954. Christianity and history. London: Camelot Press.

Dreyer, P S 1958. Historisme en die Christendom. HTS 14/1, 13-31. 
Dreyer, P S 1966. Hoofprobleme van die filosofie en die teologie van die geskiedenis. HTS 22/4, 141-162.

HAT 1994. $s v$ Moreel.

Hagenbach, K R 1896. De ontwikkelinsgeschiedenis der christelijke leerstukken. Utrecht: Kemmink en Zoon.

Hess, H E 1974. Theologie und Religion bei Johann Salomo Semler: Ein Beitrag zur Theologiegeschichte des 18. Jahrhunderts. Augsburg: W Blasaditsch.

Heussi, K 1976. Kompendium der Kirchengeschichte. Tübingen: Mohr.

Hohlwein, H 1965. s v Johann Salomo Semler. RGG.

Hornig, G 1975. Der Perfektibilitätsgedanke bei J S Semler. ZThk 72/4, 381-397.

Klapwijk, J 1933. Tussen historisme en relativisme: Een studie over de dynamiek van het historisme en de wijsgerige ontwikkelingsgang van Ernst Troeltsch. Assen: Van Gorkum.

Kraus, H J 1956. Geschichte der historisch-kritischen Erforschung des Alten Testaments von der Reformation bis zur Gegenwart. Neukirchen: Kreis Moers.

Lee, H B 1992. Historical criticism of the Bible. DD-Proefskrif, Potchefstroomse Universiteit vir CHO.

Lohse, B 1985. A short history of Christian doctrine. Philadelphia: Fortress.

Mühlenberg, E 1980. Epochen der Kirchengeschichte. Heidelberg: Quelle \& Meyer.

Moeller, B 1979. Geschichte des Christentums in Grundzügen. Gottingen: Vandenhoeck \& Ruprecht.

Pont, A D 1978. Kerkgeskiedenis. Pretoria: HAUM.

- s a. Inleiding tot die studie van die kerkgeskiedenis. Ongepubliseerde klasaantekeninge, Departement Kerkgeskiedenis (Afd A), Universiteit van Pretoria.

Schmidt, M 1965. s v Kirchengeschichte. RGG.

Schulze, L F 1988. Geloof deur die eeue. Pretoria: N G Kerkboekhandel.

Selge, K V 1982. Einfuhrung in das Studium der Kirchengeschichte. Darmstadt: Wissenschaftliche Buchgesellschaft.

Semler, J S 1967. Abhandlung von freier Untersuchung des Canon. Gütersioh: Gerd Mohn.

Stoop, J A 1973. Kerkgeskiedenis. Ongepubliseerde klasaantekeninge BD III Gids 1, Universiteit van Suid-Afrika.

Strauss, D F 1984. Das Leben Jesu Kritisch bearbeitet, vol 1. Tübingen: Osiandersche Buchandlung.

Meinecke, F 1959. Die Enstehung des Historismus, vol 3. München: R Oldenbourg. Van Aarde, A G 1995. Kerk en teologie op pad na die derde millennium: 'n Paradigmatiese verskuiwing van middelmatige aard. HTS 51, 13-38.

Van Itterzon, G P \& Nauta, D 1964. De Geschiedenis van de kerk, vol 4. Kampen: Kok. 
Van Itterzon, G P \& Nauta, D 1964. De Geschiedenis van de kerk, vol 7. Kampen: Kok.

Van Jaarsveld, F A 1980. Westerse historiografie en geskiedenisfilosofie. Pretoria: HAUM.

Van Niftrik, G C 1966. De vooruitgang der mensheid. Nijkerk: Callenbach.

Waldenfels, H 1977. Die Offenbarung: Von der Reformation bis zur Gegenwart. Freiburg: Herder.

Weber, O 1988. Foundations of Dogmatics, vol 1. Michigan: Grand Rapids. Walker, W 1986. A history of the Christian church. Edinburgh: T \& T Clark. Wolf, E 1965. s v Sigmund Jakob Baumgarten. RGG. 